\title{
Is This Business or Education? When Education Becomes a Commodity
}

\author{
Faatimah M. Murad \\ Simon Fraser University
}

\begin{abstract}
Quality education is a goal sought by multiple countries around the world; to ensure this quality, systems and standards were developed to assist in achieving this goal (Stensaker, 2014). The influence of political agendas caused education in the West to be seen more as a "consumer good" rather than a "public service", as practiced in European countries (Stensaker, 2014). The influence of such a business-driven approach renders Western education as one that is lagging and in need of reform (Altbach, 2015). Using the Tylerian objectives-based approach as a reference point, this research paper aims to unravel the links between the ethical evaluations in business compared to that in education. This is made possible through the use of the internationally recognized and listed Canadian standards. For education: the Canadian Evaluation Society, BC Ministry of Education, and Teachers Regulation Branch are referenced. For business, the International Ethics Standards is used when referencing the ethical framework. The convergence between the two fields of business and education is depicted through the international students who are being drawn into the system and placed in English Language Learner (ELL) programs. The use of business schemas and the references to economical benefits in the recruitment process, along with other factors are mentioned to support this as an example of convergence.
\end{abstract}

Keywords: business, education, evaluation, ethical standards, ELL 


\section{The Commoditization of Education: An Evolving Process}

From a Tylerian objectives-based approach, ethical standards within business as well as education are compared in this research paper to illustrate one of the processes through which education is evolving into a business. The presence of officially recognized ethical evaluation standards by the respective associations of business and education, allows this to be a more accurate and cohesive object of comparison. In drawing this link between business and education, I illustrate the growing convergence between these fields, in a world fixated on economy and value, via the ever-increasing intakes of international students and their placement in English Language Learner (ELL) programs. Stemming from the Tylerian approach, the objectives-based approach adds a broader form of applicability to Tyler's initial work as it adds focus on the formative and summative aspects of a program, in addition to the behavioral objectives (Spaulding, 2014, p.46). The Tylerian objectives-based approach is chosen as the reference point for a number of reasons: (1) it is "considered to be the first education evaluation of its kind," (2) elements of [it] can be found in evaluations conducted today, (3) it is used in evaluations for government funded programs, (4) it focuses on judging the merit of a program based on its objectives and set benchmarks (Spaulding, 2014, p.46).

\section{Literature Review}

The emergence of a direct and deliberate connection between the fields of education and business are not unforeseen, rather it has been a topic of discussion for decades. In their article on The Cult of Citizenship Education, Alan Sears and Emery Hyslop-Margison (2006) demonstrate how the political discourse often leads to educational reform and how the meaning of citizenship is influenced by the contributions individuals are able to add to the system. Reviewing the International Student Recruitment: Policies and Developments in Selected Countries, Becker and Kolster (2012) relate the increasing global integration of international students into broader forms of the higher cooperation, to the economic and political power shifts in the East. A downward mobility in the West and an upward mobility in the East compares population dynamics of age, birthrates, graduates, and workforce costs. This reveals old and declining Western populations, below replacement birthrates, scarcity of the 'right' graduates, and high workforce costs; opposites of the case in the East (Holmes, 2008).

Becker and Kolster (2012) note how the policies emphasize the importance of maintaining these continuous recruitment efforts; they highly consider what would appeal to foreign students based on perceptions. One instance is found in the advertisements of what they offer, such as "high-quality education programmes and support mechanisms for international students" (Becker \& Kolster, 2012, pg.5). In line with these policies, Douglas Todd (2016), a columnist for the Vancouver Sun and the Chair for the International Association of Religion Journalists (IARJ), reported that "campaigns to attract foreign students and their money to Canadian campuses are increasingly assertive." Higher Education Minister, Andrew Wilkinson, announced that "B.C. already has a third of this country's 330,000 foreign students, [and] efforts are escalating to bring more, especially to Metro Vancouver" (Todd, 2016). Todd also noted 
that Canadian university officials were excited about the political conditions in the United States, "with the election of immigration-wary Donald Trump as U.S. president, foreign-student interest in Canada is soaring, even while Canada already has three times as many foreign students per capita as the U.S.” (Todd, 2016). Environmental push factors such as added cultural diversity, languages, and ethical values, all serve as a "sales pitch" to attract an even greater number of international students under this label of higher quality education (Becker \& Kolster, 2012, p.14). The use of terms such as "adding value", "economic benefit", and "political policy" in the field of education inevitably reflects a resemblance to the field of business and trades more than anything (Kaplan, 2015, p.126). In a comparison of basic business mission statements and that of the BC Ministry of Education, a common "formula" is visible in the structure and format of these statements. With its function in guiding organizational culture and perspective, the mission statement plays a role in defining objectives and orientations towards cooperation and innovation, communicating concern for stakeholders, and identifying core philosophy around development and growth (Babnik, Breznik, Dermol, \& Trunk Širca, 2014). Following suit, the BC Ministry of Education upgraded their mission statement from previous versions that were much shorter and inconclusive to a longer, more detailed one that is more inclusive of the growing number of stakeholders and private sectors (Ministry of Education, 2016). In assessing the business-like motives being used for recruitment in a number of countries around the world, Altbach and Knight (2007) reported the following:

Many countries recruit international students to earn profits by charging high fees-including Australia, Canada, the United Kingdom, and the United States. International graduate students also provide research and teaching services for modest compensation. International students also spend significant amounts of money in the host countries-an estimated $\$ 12$ billion to the U.S. economy, for example. (p. 292)

The BC Jobs Plan includes international education as a key sector that serves as a major profit inflow; they had set their goal to increase the number of international students to $50 \%$ by 2016. In 2015, they had achieved a $44 \%$ increase in the number of international students accessing Canadian education sites from 2010 - a total of 130,053 students in British Columbia, 51,130 from China alone (Ministry of Education, 2017). The profits made with international student tuition fees and expenditures were at an estimated $\$ 3.5$ billion; a major factor in supporting 29,300 jobs (Ministry of Education, 2017).

Furthermore, the BC Council on Admissions and Transfer (2016) relies on the Degree Quality Assessment Board (DQAB) for their quality assurance in both public and private sectors, they do not charge themselves with any responsibility for quality assessment or program recognition (BCCAT, 2016). This policy enables institutions to develop "skillset builder" programs and courses, each of which sponsored and labeled to be of high quality (Altbach, 2015). The latter inspired the term "degree mills" as a reference to the growing number of institutions that provide a vast plethora of credentials, while simultaneously presenting a greater challenge for the DQAB to consistently follow-up and assure 
quality and validity; especially with the massive amounts of data being produced (Altbach, 2015). In his book, Kemal Guruz (2011) reveals the effects that higher fees paid by international students have on the global education market, he states trades take place in the following services and products:

(1) Education-related publishing, (2) educational equipment and course material, (3) consultancy services provided to ministries and companies, (4) guidance counseling, and placement services provided to students, (5) preparatory teaching, especially teaching of English as a foreign language, and (6) testing. (p. 146)

Ironically, however, the increased numbers of foreign students, who struggle with language in Canadian classes, has a negative impact on the quality of education (Todd, 2016). Patrick Feeney, a BC-based education professor, "witnessed how both domestic students and foreign students are being shortchanged, especially those in humanities and social sciences classes" (Todd, 2016, para. 26). Another alarming realization comes with the modified requirements and admission grades, so as to secure the acceptance of foreign students and their financial contributions, due to this the market values for degrees earned by domestic students are decreasing (Todd, 2016).

When comparing ethical values in education to that of business, both have been officially outlined, as well as nationally and internationally recognized. The Joint Committee on Standards for Educational Evaluation (JCSEE) developed ethical standards that were adopted by the Canadian Evaluation Society (CES) in January 2012 (CES, 2014). The essential components of these evaluation standards are: "utility, feasibility, propriety, accuracy, and evaluation accountability" (Spaulding, 2014, p.42). Although worded differently, the BC Ministry of Education Teacher Regulation Branch (TRB) (2012) also lists a similar eight standards directed at teachers:

1. Educators value and care for all students and act in their best interests.

2. Educators are role models who act ethically and honestly.

3. Educators understand and apply knowledge of student growth and development.

4. Educators value the involvement and support of parents, guardians, families and communities in schools.

5. Educators implement effective practices in areas of classroom management, planning, instruction, assessment, evaluation and reporting.

6. Educators have a broad knowledge base and understand the subject areas they teach.

7. Educators engage in career-long learning.

8. Educators contribute to the profession (British Columbia. Ministry of Education, 2012, p. 4). 
In business, the Ministry of Finance (2014) states the ethical standards. Although direct and concise, each form of business (i.e. banks, phone companies, product companies, foods companies, etc.) has specified and outlined its own version of these standards that are internationally recognized and approved. The specific selection of the International Evaluation Standards here is due to its unique compilation and general applicability (King, Grant \& Berkemeier, 2016). The evaluation standards include ten components that overlap with those of education mentioned previously. These standards are: accountability, confidentiality, conflict of interest, financial responsibility, integrity, lawfulness, reflection, standard of service, transparency, and trust (King, Grant \& Berkemeier, 2016). Each standard is further defined, as are those of education. Using the clearly defined and recognized definitions of each standard, an illustration of the parallelism between them is demonstrated (see Table 1).

Table 1: A comparison between the CES, BC Ministry of Education, and IES standards.

\begin{tabular}{|c|c|c|}
\hline $\begin{array}{l}\text { Canadian Evaluation } \\
\text { Society }\end{array}$ & $\begin{array}{l}\text { BC Ministry of } \\
\text { Education }\end{array}$ & $\begin{array}{l}\text { IES of } \\
\text { Business }\end{array}$ \\
\hline $\begin{array}{l}\text { Propriety Standards (P): } \\
\text { (P3) Human Rights and } \\
\text { Respect. }\end{array}$ & $\begin{array}{l}\text { Educators value and } \\
\text { care for all students } \\
\text { and act in their best } \\
\text { interests. }\end{array}$ & $\begin{array}{l}\text { Accountability } \\
\text { Confidentiality }\end{array}$ \\
\hline $\begin{array}{l}\text { (P6) Conflicts of Interests: } \\
\text { Evaluations should openly } \\
\text { and honestly identify and } \\
\text { address conflicts of interest } \\
\text { that may compromise the } \\
\text { evaluation. }\end{array}$ & $\begin{array}{l}\text { Educators are role } \\
\text { models who act } \\
\text { ethically and } \\
\text { honestly. }\end{array}$ & $\begin{array}{l}\text { Integrity } \\
\text { Trust } \\
\text { Lawfulness }\end{array}$ \\
\hline $\begin{array}{l}\text { Utility Standards (U): } \\
\text { (U2) Attention to } \\
\text { stakeholders } \\
\text { Accuracy Standards (A): } \\
\text { (A1) Trustworthy } \\
\text { Conclusions and Decisions. }\end{array}$ & $\begin{array}{l}\text { Educators } \\
\text { understand and } \\
\text { apply knowledge of } \\
\text { student growth and } \\
\text { development. } \\
\text { This knowledge is } \\
\text { used to assist } \\
\text { educators in making } \\
\text { decisions about } \\
\text { curriculum, } \\
\text { instruction, } \\
\text { assessment, and } \\
\text { classroom } \\
\text { management. }\end{array}$ & $\begin{array}{l}\text { Standard of } \\
\text { Service } \\
\text { Transparency }\end{array}$ \\
\hline $\begin{array}{l}\text { (P1) Responsive and } \\
\text { Inclusive Orientation }\end{array}$ & $\begin{array}{l}\text { Educators value the } \\
\text { involvement and } \\
\text { support of parents, }\end{array}$ & $\begin{array}{l}\text { Trust } \\
\text { Transparency }\end{array}$ \\
\hline
\end{tabular}




\begin{tabular}{|c|c|c|}
\hline & $\begin{array}{l}\text { guardians, families } \\
\text { and communities in } \\
\text { schools. }\end{array}$ & \\
\hline $\begin{array}{l}\text { Feasibility Standards (F): } \\
\text { (F1) Project Management } \\
\text { (U7) Timely and } \\
\text { Appropriate } \\
\text { Communication and } \\
\text { Reporting }\end{array}$ & $\begin{array}{l}\text { Educators } \\
\text { implement effective } \\
\text { practices in areas of } \\
\text { classroom } \\
\text { management, } \\
\text { planning, } \\
\text { instruction, } \\
\text { assessment, } \\
\text { evaluation and } \\
\text { reporting. }\end{array}$ & $\begin{array}{l}\text { Transparency } \\
\text { Conflict of } \\
\text { Interest }\end{array}$ \\
\hline $\begin{array}{l}\text { (U1) Evaluator credibility } \\
\text { (A8) Communication and } \\
\text { Reporting }\end{array}$ & $\begin{array}{l}\text { Educators have a } \\
\text { broad knowledge } \\
\text { base and } \\
\text { understand the } \\
\text { subject areas they } \\
\text { teach. }\end{array}$ & $\begin{array}{l}\text { Accountability } \\
\text { Reflection }\end{array}$ \\
\hline $\begin{array}{l}\text { (U6) Meaningful Processes } \\
\text { and Products } \\
\text { Evaluation Accountability } \\
\text { Standards (E): } \\
\text { (E2) Internal } \\
\text { Metaevaluation }\end{array}$ & $\begin{array}{l}\text { Educators engage in } \\
\text { career-long } \\
\text { learning. } \\
\text { Educators develop and } \\
\text { refine personal } \\
\text { philosophies of education, } \\
\text { teaching and learning that } \\
\text { are informed by theory and } \\
\text { practice. Educators } \\
\text { identify their professional } \\
\text { needs and work to meet } \\
\text { those needs individually } \\
\text { and collaboratively. }\end{array}$ & $\begin{array}{l}\text { Standard of } \\
\text { Service } \\
\text { Reflection }\end{array}$ \\
\hline $\begin{array}{l}\text { (E3) External } \\
\text { Metaevaluation }\end{array}$ & $\begin{array}{l}\text { Educators } \\
\text { contribute to the } \\
\text { profession. }\end{array}$ & $\begin{array}{l}\text { Financial } \\
\text { Responsibility }\end{array}$ \\
\hline
\end{tabular}

(CES, 2014; IES, 2016; Mertens, D., 2015; Ministry of Ed., 2012)

With this comparison, the overlap between the general standards is astonishing; each standard has an equivalent standard in the respective fields. The identified links between business and education has also been inspired by the objects-based approach, a method primarily focused on whether or not objectives have been met (Mertens, 2015). The underlying goals of securing profit when attracting international students is met, the benefits of this model are evident in the economical success as noted in numerous articles and statements of government representatives (Todd, 2016). Though economic and social mobility are significantly represented with ELL access to higher education, the significant 
benefits to society as a whole plays an influential role in giving incentive to policymakers and educators to ensure their access into postsecondary institutions (Flores \& Drake, 2014).

Reflecting upon the Tylerian objectives-based approach, research studies conducted around motivation factors and assessment are extensive. In a UNICEF (2014) report, many international students had opted for studies abroad in order to escape exam pressures, especially those from Eastern Asian countries, many others for commercial advantages pertaining to obtaining degrees from the West, and others for language acquisition. Researchers in the field of international studies, formed a model that demonstrates the acquisition of "an advanced degree for personal satisfaction or to improve foreign language skills...In addition [to finding] it valuable to have an advanced degree from a Western country" among the most motivational factors to study abroad (Becker \& Kolster, 2012, p.13). With these motivations, there is a shared general lack of awareness regarding recruitment policies and multinational education commercialization (BCME, 2013). The latter has also led to the rise of a competitive education industry through the application of market criteria in a process of commoditization; the impact of this process is not yet understood and is more frequently being referred to as "a very real threat" to any organization and career (Haar, 2014; Holmes, 2008).

To understand the more accurate underlying goal of gaining profit as opposed to promoting education and accredited skill development, it is important to recognize the extensive development in the financial division over those in the curriculum division (BCME, 2013). Despite the massive numbers of international students accessing a market system of education notwithstanding its reform and state of struggle to accommodate for their needs, much of the international student curriculum focuses on language acquisition rather than subject matter and basic conceptual understanding (Mollaei \& Rahnama, 2012). The most recent updates by the Ministry of Education (2017) state "work is underway to develop a refreshed B.C. International Education Strategy that will build on progress to date" (para. 17). Moreover, international student standards are limited with the typical focus on the three domains of reading, writing and oral expression (ELL, 2001).

In the final assessment of this topic, a question comes to mind regarding the stakeholders in this comparison. Who are the stakeholders? Considering the Tylerian objectives-based approach is foundational to the postpositivist paradigm used in evaluation methods (Mertens, 2015). For example, theorist Donald Campbell (2007) built on the works of postpositivism to include a theory-based evaluation approach that depends on stakeholders' theories, available social science theories, or both. Mertens (2015) explains:

The role of the evaluator is to bring a theoretical framework from existing social science theory to the evaluation setting. This would add insights to the structure of the program and its effectiveness that might not be available to the stakeholders in the setting. (p. 55) 
The insight and structure that is unavailable to the "stakeholders in the setting" can be seen as the financial profit reaped from the international students in the setting of the ELL programs (Mertens, 2015). Correspondingly with the ethical standards discussed in the fields of education and business: beneficence, respect, and justice, are the three ethical principles within research (Mertens, 2015). These principles contribute to the fundamentals of research and evaluation, they are meant to ensure maximum benefit, recognition, and fairness will be attributed to all the stakeholders (Mertens, 2015). Satisfying the set prominent motivations of the international students, while boosting the economy in the foreign country is the trade at hand, the business being practiced, and the goal being met.

Globalization is seen as central to the world of finance and trade, communications, and information technologies; with governments becoming more national in form, education is becoming more central to government, enabling "issues of identity and difference [to] become more important in the politics of education" (Marginson, 2010). Due to this connection, the fields of business and education are intertwined in many areas; at times, it is difficult to distinguish them apart. The demonstration of ethical standards and the comparisons within them significantly contribute to this phenomenon.

\section{Discussion}

Restricted to the literature, this research paper is limited in the scope and impact of evaluation standards on the respective fields. How well they are applied and aligned with the intended goals of the program; publicly accessible fidelity and validity records are scarce. The latter may also influence the accuracy of the information. There is a lot of focus on the economical benefit within the literature, but there is not much of a focus on the compliance with evaluation standards by any of the administering institutions, much of which differ amongst different school districts (Callahan, Wilkinson, Muller, \& Frisco, 2009, p. 361). When researching this topic, it is suggested qualitative or mixed methods be used in the data collection process (Flores \& Drake, 2014). The ever-increasing output of data poses challenges for the DQAB, some of these challenges are related to the following: capacity, intent, validation, activities and fidelity of delivery (Spaulding, 2014). These are separately explained below.

Limitations in capacity and intent. When reviewing if all aspects of the program are ready for implementation, and whether all employees and recruits are aware of the goals of the program, it is evident from the lack of a fully developed curriculum and the discrepancies between school districts that this evaluation objective has yet to be met (Callahan, et al., 2009, p. 361; Ministry of Education, 2017; Mollaei \& Rahnama, 2012). Teachers rely on training sessions that are mostly "conventional, narrow and highly prescribed not experiential" (Mollaei \& Rahnama, 2012, p.268).

Limitations in validation. When assessing the quality and level of appropriateness of a program, whether or not it meets national standards, this 
objective is evaluated through materials that are criteria-based (Spaulding, 2014). Considering the number of "degree mills" that have established, and the number of "skillset builder" courses that are taught, specifically when the BCCAT is not responsible for these validations, the politics brought into the equation raises a deeper concern for asset security rather than program delivery (Altbach \& Knight, 2007; BCCAT, 2016).

Limitations in activity and fidelity of delivery. When researching alignment with desired goals and correctness of conduct within, research is scarce. The goals that are amplified surround economical values and public benefit (Todd, 2016).

Intermediate and end outcomes concerning those participating in the programs are often successful for the political incentives that are attached; this is made possible through entry-level standards modifications for maximizing international student acceptance (Flores \& Drake, 2014; Spaulding, 2014; Todd, 2016).

\section{Conclusions and Future Study}

As the most widely used approach in evaluation, one that is required by government agencies and foundations for evaluations of programs that they fund, the objectives-based approach relies on preset goals (Spaulding, 2014). With driven intentions and campaigns propagating news of highest-quality education and degrees in the West, those seeking to experience a different system are drawn in (Todd, 2016). Research concerning international student achievement and academic preparation indicates greater success rates in more advanced coursework than their counterparts placed in lesser-advanced coursework (Callahan, et al., 2009). As a deliverer of the content, I would identify as a stakeholder in the equation as well; the system not only benefits me by securing a position and a job, but also by promoting a sense of satisfaction with what I offer my students. In my practice and application of these evaluation standards, I make a conscious effort to emphasize the goals of a certain topic. In addition to the English language development, I encourage students to discuss concepts using their first languages to ensure their maximum benefit.

When analyzing future studies and approaches, there is a great push to design interventions that account for "the complex nature of ELL student designation, particularly by race, ethnicity, and time in a language program (Flores \& Drake, 2014). Other future directions emphasize the importance of forming ethical attitudes towards ELL individuals, cultural sensitivity and the recognition of their differences (Squire, 2008). Research has also shown the application of business ethics on students does not reveal any positive effects on student attitudes or on their perceptions of ethical behaviors (Kavathatzopoulos, 1993). The provision of a rich experience, ethically sensitive, and well-rounded content are components of a valuable evaluation strategy for ELL programs compared to a strategy that has a general focus on profit and economy. 


\section{References}

Altbach, P. (2015). Knowledge and education as international commodities. International higher education, (28).

Altbach, P. \& Knight, J. (2007). The Internalization of Higher Education: Motivations and Realities. Journal of Studies in International Education, 11( 3/4), 290-305.

Babnik, K., Breznik, K., Dermol, V., \& Trunk Širca, N. (2014). The mission statement: Organisational culture perspective. Industrial Management \& Data Systems, 114(4), 612-627. doi:10.1108/IMDS-10-2013-0455

BCCAT, (2016). Accreditation and Quality Assurance. British Columbia Council on Admissions and Transfer. Retrieved from http://www.bccat.ca/system/accreditation

BCME. (2013). K-12 International Education Regional Roundtables. British Columbia Ministry of Education. p.1-34.

Becker, R., \& Kolster, R. (2012). International student recruitment policies and developments in selected countries. Netherlands Organisation for International Cooperation in Higher Education. The Hague: Nuffic.

Callahan, R., Wilkinson, L., Muller, C., \& Frisco, M. (2009). ESL Placement and Schools Effects on Immigrant Achievement. Educational Policy. 23(2), p.355-384.

CES. (2014). Program Evaluation Standards. Canadian Evaluation Society. Retrieved from http://evaluationcanada/program-evaluation-standards

ELL. (2001). English as a Second Language: Standards. National Library of Canada Cataloguing in Publication Data. Ministry of Education, British Columbia.

Flores, S. M. \& Drake, T. A. (2014). Does English Language Learner (ELL) Identification Predict College Remediation Designation?: A Comparison by Race and Ethnicity, and ELL Waiver Status. The Review of Higher Education 38(1), 1-36. The Johns Hopkins University Press. Retrieved December 13, 2016, from Project MUSE database.

Guruz, K. (2011). Higher Education and International Student Mobility in the Global Knowledge Economy. Albany, US: SUNY Press. Retrieved from http://www.ebrary.com.proxy.lib.sfu.ca

Haar, C. K. (2014). Lieberman's three-sector competitive education industry. Journal of School Choice, 8(2), 277-281. 
Holmes, A., \& Taylor \& Francis eBooks. (2008). Commoditization and the strategic response. Burlington, VT;Aldershot, England;: Gower.

Kaplan, R. S. (2015). What you really need to lead: The power of thinking and acting like an owner. Boston, MA: Harvard Business Review Press.

Kavathatzopoulos, I. (1993). Development of a cognitive skill in solving business ethics problems: The effect of instruction. Journal of Business Ethics, 12(5), 379 .

King, P. B., Grant, T., \& Berkemeier, R. (2016). International Ethics Standards: An Ethical Framework for the Global Property Market. International Ethics Standards Coalition (IESC). Retrieved from https://iescoalition.org/standards/

Marginson, S. (2010). After globalization: emerging politics of education. Journal of Education Policy, 14(1). p.19-31.

Mertens, D. M. (2015). Research and evaluation in education and psychology: Integrating diversity with quantitative, qualitative, and mixed methods (4th ed.). Thousand Oaks, CA: SAGE Publications, Inc.

Ministry of Education. (2012). Standards for the Education, Competence \& Professional Conduct of Educators in British Columbia (4 ${ }^{\text {th }}$ ed.) [Victoria, B.C.]:Ministry of Education.

Ministry of Education. (February 2016). 2016/17-2018/19 Service Plan. Retrieved from www2.gov.bc.ca/gov/contents/governments/organizationalstructure/ministries-organizations/ministries/education

Ministry of Education. (January 2017). FACTSHEET: International students in B.C. Retrieved from: https://news.gov.bc.ca/09052

Mollaei, F. \& Rahnama, H. (2012). Experiential Education Contributing to Langauge Learning. International Journal of Humanities and Social Sciences. Center for Promoting Ideas. USA. 2(21), pp. 268-279.

Sears, A. M.; Hyslop-Margison, E. J. (2006). The Cult of Citizenship Education. Troubling Places for Citizenship Education. (pp.13-24). New York, Peter Lang. Pub.

Spaulding, D. T. (2014). Research Methods for the Social Sciences Ser. : Program Evaluation in Practice : Core Concepts and Examples for Discussion and Analysis (2). Somerset, US: Jossey-Bass. 
Squire, J. R. (2008). English Language Learners: A Policy Research Brief Produced By The National Council of Teachers of English. NCTE. pp.1-8

Stensaker B. (2014) European Trends in Quality Assurance: New Agendas beyond the Search for Convergence?. In: Rosa M.J., Amaral A. (eds) Quality Assurance in Higher Education. Issues in Higher Education. Palgrave Macmillan, London

Todd, D. (2016, December 12). The Hidden Cost of Foreign Student Policy. Vancouver Sun. 